\title{
Metabolic engineering of carbohydrate metabolism systems in Corynebacterium glutamicum for improving the efficiency of L-lysine production from mixed sugar
}

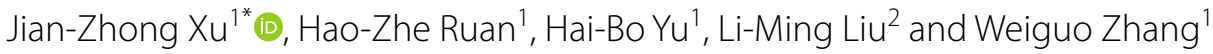

\begin{abstract}
The efficiency of industrial fermentation process mainly depends on carbon yield, final titer and productivity. To improve the efficiency of L-lysine production from mixed sugar, we engineered carbohydrate metabolism systems to enhance the effective use of sugar in this study. A functional metabolic pathway of sucrose and fructose was engineered through introduction of fructokinase from Clostridium acetobutylicum. L-lysine production was further increased through replacement of phosphoenolpyruvate-dependent glucose and fructose uptake system (PTS ${ }^{\mathrm{Gl}}$ and PTS ${ }^{\text {Fru }}$ ) by inositol permeases (IolT1 and lolT2) and ATP-dependent glucokinase (ATP-GIK). However, the shortage of intracellular ATP has a significantly negative impact on sugar consumption rate, cell growth and L-lysine production. To overcome this defect, the recombinant strain was modified to co-express bifunctional ADP-dependent glucokinase (ADP-GIK/PFK) and NADH dehydrogenase (NDH-2) as well as to inactivate SigmaH factor (SigH), thus reducing the consumption of ATP and increasing ATP regeneration. Combination of these genetic modifications resulted in an engineered C. g/utamicum strain K-8 capable of producing $221.3 \pm 17.6 \mathrm{~g} / \mathrm{L}$ L-lysine with productivity of $5.53 \mathrm{~g} / \mathrm{L} / \mathrm{h}$ and carbon yield of $0.71 \mathrm{~g} / \mathrm{g}$ glucose in fed-batch fermentation. As far as we know, this is the best efficiency of L-lysine production from mixed sugar. This is also the first report for improving the efficiency of L-lysine production by systematic modification of carbohydrate metabolism systems.
\end{abstract}

Keywords: L-lysine, Corynebacterium glutamicum, Carbohydrate metabolism systems, Fructokinase, ATP availability

\section{Background}

L-lysine, an essential amino acids for animals and humans, is widely used as feed additive, composition of pharmaceuticals, and feedstock for cosmetics and polymer materials [1]. With the expansion and deep-going of L-lysine's applications, the demands for L-lysine are growing rapidly in global marketplace [2]. In industry, L-lysine is mainly produced by microbial fermentation [3,

\footnotetext{
*Correspondence: xujianzhong@jiangnan.edu.cn

${ }^{1}$ The Key Laboratory of Industrial Biotechnology, Ministry of Education,

School of Biotechnology, Jiangnan University, 1800\# Lihu Road, Wuxi 214122, China

Full list of author information is available at the end of the article
}

4]. Therefore, the excellent L-lysine producers and inexpensive fermentation feedstock are absolutely vital for fermentation to reduce the production costs.

Corynebacterium glutamicum and its subspecies are widely used as workhorse for producing $\mathrm{L}$-lysine in industry $[4,5]$, because they possess the wide carbon resource utilization spectrum, including carbohydrate feedstock (e.g., glucose, fructose, sucrose and pentose) and noncarbohydrate feedstock (e.g., n-alkane, ethanol and organic acids) [6, 7]. In industry, the L-lysine production by $C$. glutamicum is primarily using glucose, fructose, sucrose or molasses as carbon sources, especially glucose [8]. Carbohydrate uptake and phosphorylation are mainly executed by phosphoenolpyruvate- carbohydrate

c) The Author(s) 2020. This article is licensed under a Creative Commons Attribution 4.0 International License, which permits use, sharing, adaptation, distribution and reproduction in any medium or format, as long as you give appropriate credit to the original author(s) and the source, provide a link to the Creative Commons licence, and indicate if changes were made. The images or other third party material in this article are included in the article's Creative Commons licence, unless indicated otherwise in a credit line to the material. If material is not included in the article's Creative Commons licence and your intended use is not permitted by statutory regulation or exceeds the permitted use, you will need to obtain permission directly from the copyright holder. To view a copy of this licence, visit http://creativeco mmons.org/licenses/by/4.0/. The Creative Commons Public Domain Dedication waiver (http://creativecommons.org/publicdomain/ zero/1.0/) applies to the data made available in this article, unless otherwise stated in a credit line to the data. 
phosphotransferase system (PTS) consisting of 1 membrane-bound carbohydrate-specific EIIABC component (EII) and 2 cytoplasmic components (i.e., enzyme I (EI) and histidine protein (HPr)) [9]. Previous researches have pointed out that the productivity of target products goes hand in hand with carbohydrate uptake capacity [10-12]. Although carbohydrate uptake capacity is increased with increasing the expression levels of the key genes in PTS, it will lead to overflow metabolism [10, 13]. In addition, PTS uses phosphoenolpyruvate (PEP) as phosphoryl group donor, resulting in the low intracellular PEP and the increase of flux through PEP carboxykinase [14]. It is a problem for realizing the efficient production of L-lysine that how to balance carbohydrate uptake capacity and carbohydrate consumption rate.

Aside from engineering PTS to increase the uptake rate of carbohydrates, a number of studies indicated the important role of PTS-independent carbohydrate uptake systems (i.e., non-PTS) for cell growth and production of target products (including L-lysine) by addition of myoinositol to increase genes iolT1 and iolT2 expression level [15], by deletion or rational modification of transcriptional regulator IolR to derepress the expression of iol-genes [16-18], or by co-overexpression of the myoinositol permease (i.e., IolT1 and IolT2; encoded by genes iolT1 and iolT2, respectively) and glucokinases (e.g., GlK and PpgK; encoded by genes $g l k$ and $p p g K$, respectively) [19-22]. In C. glutamicum, the coupling system of myoinositol permeases and glucokinases (designed as IGS, similarly hereinafter) has been proved to participate in carbohydrate uptake and phosphorylation $[16,17,21-$ 23], which belongs to non-PTS [23]. The IGS uses ATP or PolyP $_{\mathrm{n}}$ as phosphoryl group donor rather than PEP in $C$. glutamicum, thus increasing PEP availability [24]. In IGS, the carbohydrates are firstly transported into intracellular by myo-inositol permeases, and are then phosphorylated by glucokinases. However, IolT1 and IolT2 show a lower affinity for glucose as compared with EII $_{\text {Glc }}$ [19]. Moreover, the expression of iolT1 is repressed by IolR [18]. Lara et al. has proved that overflow metabolism can be circumvented with replacement of PTS by the coupling system of galactose permease and glucokinases in Escherichia coli [13]. This gives us a positive reference to construct L-lysine high-producing strain to improve the efficiency of L-lysine production.

Molasses, the major by-product of sugar industry, is a frequently-used and economical carbon source for producing many valuable fine chemicals by microbial fermentation, including ethanol [25], vitamin $B_{12}$ [26], docosahexaenoic acid [27]. This is because that molasses contains abundant nourishments and biological active substances, such as sugars, amino acids, inorganic salts, nicotinic acid, folic acid, thiamine, etc. [7, 27, 28].
Therefore, reuse of molasses is important for sugar industry to improve economic returns. At present, molasses is one of the main feedstock for amino acids production (e.g., L-lysine [10, 29], L-glutamate [30], poly- $\gamma$-glutamic acid [31]), because its main component is sucrose [7]. Sucrose can be easily hydrolyzed to glucose and fructose [7]. Although molasses is wildly used for amino acid fermentation in industry, most published work focus on investigating the consumption rate of carbohydrates at single glucose, fructose, or sucrose as carbon source [3234]. How to improve the utilization efficiency of molasses is an important problem to be solved in our present-day amino acids industry.

Corynebacterium glutamicum K-1 (i.e., C. glutamicum JL-6 $\left.\Delta p c k:: p p c \Delta o d x:: p y c \Delta \mathrm{P} 1 g l t A / \mathrm{P}_{\text {tac-M }} g d h\right)$ is a $\mathrm{L}$-lysine high-yielding strain with L-lysine production of $181.5 \pm 7.65 \mathrm{~g} / \mathrm{L}$ after cultivating $48 \mathrm{~h}$ in fed-batch culture [3]. However, the productivity of C. glutamicum K-1 is lower as compared with the previous results $(3.78 \mathrm{~g} / \mathrm{L} / \mathrm{h}$ v.s. $4.00 \mathrm{~g} / \mathrm{L} / \mathrm{h}$ ) [10]. The aim of this study was to make use of mixed sugar for L-lysine production by C. glutamicum $\mathrm{K}-1$, in which the mixture of glucose and beet molasses was designed as mixed sugar. Furthermore, in order to improve the efficiency of L-lysine production from mixed sugar, we focused on the genetic modification of genes involved in carbohydrate metabolism systems to increase the L-lysine productivity of C. glutamicum K-1. The results verified that carbohydrate metabolism system is a good target for improving amino acid production.

\section{Results and discussion}

\section{Hetero-expression of ScrK increases L-lysine production} in C. glutamicum K-1 from mixed sugar

According to our previous results [7], total sugar concentration in beet molasses, supplied by COFCO Biochemical (Anhui) Co., Ltd., (Anhui, China), was about $50 \%$, and especially sucrose was the most important components (more than 47\%). Sucrose was assimilated and phosphorylated by sucrose-PTS $\left(\mathrm{PTS}^{\mathrm{Suc}}\right)$ in C. glutamicum to yield sucrose-6-phosphate, and then sucrose-6-phosphate was hydrolyzed to glucose-6-phosphate and fructose by sucrose-6-phosphate hydrolase [35]. However, there is no fructokinase (ScrK) in C. glutamicum [36], resulting in that the intracellular fructose should be firstly excreted into extracellular and then reassimilated via fructose-PTS (PTS ${ }^{\mathrm{Fru}}$ ). Previous results indicated that hetero-expression of ScrK is beneficial to increase the production of NADPH-dependent products with sucrose or mixed sugar as carbon source [7, 37-39]. Therefore, hetero-expression of ScrK from C. acetobutylicum at $p f k B$ gene loci was set as a potential strategy for enhancing L-lysine production on mixed sugar in this study. As a result, the resulted strain C. glutsmicum K-2 
showed no fructose efflux, whereas the extracellular fructose in original strain C. glutamicum K-1 was increased at the initial stage of fermentation on $\mathrm{CgXII}{ }^{\mathrm{IP}} \mathrm{M}$-medium (Fig. 1a). There was no obvious difference in DCW between C. glutamicum K-1 and C. glutamicum K-2, but the maximal specific growth rate $\left(\mu_{\max }\right)$ of $C$. glutamicum K-2 $\left(\mu_{\max .}=0.23 / \mathrm{h}\right)$ was higher than that of $C$. glutamicum K-1 $\left(\mu_{\text {max. }}=0.20 / \mathrm{h}\right)$ (Fig. 1b). The similar results were also obtained in the previous reports [7, 39]. However, these results are contrast to the results reported by Zhang et al. [38], in which DCW of recombinant strain with hetero-expression of ScrK was $15.5 \%$ lower than that of control strain. A possible reason is that more carbon source was used to synthesize target product. Consistent with the effect on cell growth, hetero-expression of ScrK obviously increased the L-lysine production on CgXII ${ }^{\mathrm{IP}} \mathrm{M}$-medium (Fig. 1c). In addition, the sugar consumption rate of strain K-2 increased to $7.74 \pm 0.45$ $(\mathrm{mmol} \mathrm{C}) /(\mathrm{g} \mathrm{DCW}) / \mathrm{h}$, which was $76.7 \%$ higher than that of strain K-1 $(4.38 \pm 0.47(\mathrm{mmol} \mathrm{C}) /(\mathrm{g} \mathrm{DCW}) / \mathrm{h})$ (Table 1). The point is that hetero-expression of ScrK is ineffective in cell growth and L-lysine production with glucose as sole carbon source (Table 1), possibly because of the absence of fructose in culture [7].

In addition, fed-batch fermentation was carried out in a 1-L jar fermenter containing $0.25 \mathrm{~L}$ fermentation media to test the production performance of strain K-2. Compared with strain K-1, hetero-expression of ScrK had a trend to increase L-lysine production (Fig. 2a). The L-lysine production of strain $\mathrm{K}-2$ reached to $187.3 \pm 11.7 \mathrm{~g} / \mathrm{L}$, which was $9.0 \%$ higher than that of strain K-1 $(171.8 \pm 5.6 \mathrm{~g} / \mathrm{L})$. However, it cannot be ignored that strain K-2 accumulated large amount of by-products, especially lactate, L-alanine and L-valine (Fig. 2b). The main reason for this is that carbohydrate uptake by PTS will produce pyruvate (Fig. 3), thus leading to overflow metabolism [13]. Therefore, the next plan is to modify the carbohydrate uptake system in strain $\mathrm{K}-2$ to reduce the amount of by-products.

\section{Deletion of $p t s G$ and $p t s F$ genes cause a decrease in carbohydrates consumption in C. glutamicum}

The $p t s G$ and $p t s F$ genes encode membrane-bound glucose-specific EIIABC (EII $\left.\mathrm{Glc}_{\mathrm{c}}\right)$ and fructose-specific EIIABC $\left(\mathrm{EII}_{\mathrm{Fru}}\right)$, respectively [39]. $\mathrm{EII}_{\mathrm{Glc}}$ and $\mathrm{EII}_{\mathrm{Fru}}$ facilitate glucose and fructose movement across membrane, respectively (Fig. 3). Theoretically, deletion of ptsG and $p t s F$ genes reduces the intake of sugar via PTS and thus compels strain to assimilate sugar via non-PTS. In order to verify this inference, $p t s G$ and $p t s F$ genes were deleted in strain K-2. However, the target strain C. glutamicum K-2 $\Delta p t s G$ pptsF (i.e., C. glutamicum K-3) showed bad cell growth and L-lysine production as compared with strain $\mathrm{K}-2$ on $\mathrm{CgXII}{ }^{\mathrm{IP}}$-medium with glucose or fructose as sole carbon source (Table 1). This is because PTS is the major carbohydrates uptake system in C. glutamicum [23]. In addition, although C. glutamicum possess IGS for assimilating glucose and fructose, the key components (i.e., myo-inositol permease and glucokinases) show the low expression level and the low affinity for glucose and fructose $[18,19,21]$. Interestingly, deletion of $p t s G$ and $p t s F$ genes is ineffective in cell growth and L-lysine production with sucrose or molasses as carbon source (Table 1), because glucose and fructose in culture is negligible. However, it should be noted that the production performance of strain K-3 (including DCW, L-lysine production and sugar consumption rate) was dramatically disturbed by deletion of $p t s G$ and $p t s F$ genes in fed-batch fermentation (Additional file 1: Fig. S1). C. glutamicum exhibits a strong preference for glucose as carbon source [8]. And fermentation medium and feed solution mainly contain glucose (see "Methods" section) [10]. These may be the reasons for the bad production performance of strain $\mathrm{K}-3$ in fed-batch fermentation. In consideration of the physiology of strain K-3 and the functional role of IGS, the expression levels of myo-inositol permease and glucokinases in strain K-3 should be increased to enhance the participation of IGS in carbohydrates uptake in L-lysine producer.

\section{Over-/hetero-expression of IolT1, IolT2, ATP-GIK and ADP-GIK accelerates carbohydrates consumption in PTS ${ }^{\mathrm{Glc}}$ - and PTS ${ }^{\mathrm{Fru}}$-deficient strains}

As mentioned above, C. glutamicum possess IGS for carbohydrate uptake, but myo-inositol permease and glucokinases show the low expression level and the low affinity for glucose and fructose $[18,19,21]$. To overcome these defects and to push carbohydrate into cell via IGS, the dominant strategy is to increase the expression level of myo-inositol permease and glucokinases. myo-inositol permease (e.g., IolT1 or IolT2) and glucokinases (e.g., PpgK or ATP-GIK) have been demonstrated to redirect carbohydrate uptake by IGS in C. glutamicum [19-22]. However, the expression of IolT-coding gene iolT1 is repressed by IolR [18], and deletion of IolR-coding gene iolR causes certain negative effects on strain [17]. Therefore, the special promoter of iolT1 (i.e., $\mathrm{P}_{\mathrm{o} 6}$ ) with two point mutations at position $-113(\mathrm{~A} \rightarrow \mathrm{G})$ and -112 $(\mathrm{C} \rightarrow \mathrm{G})$ replaced the nature promoter of iolT1 according to the reports by Brusseler et al. [17], and the nature promoter of IolT2-coding gene iolT2 was replaced by $\mathrm{P}_{\text {tuf }}$ promoter, and then the second copy of iolT2 gene with $\mathrm{P}_{\text {tuf }}$ promoter was introduced in strain $\mathrm{K}-3$ genome, resulting in the final engineered strain C. glutamicum $\mathrm{K}-4$. In response to these modifications, the cell growth, L-lysine production and sugar consumption rate of strain 

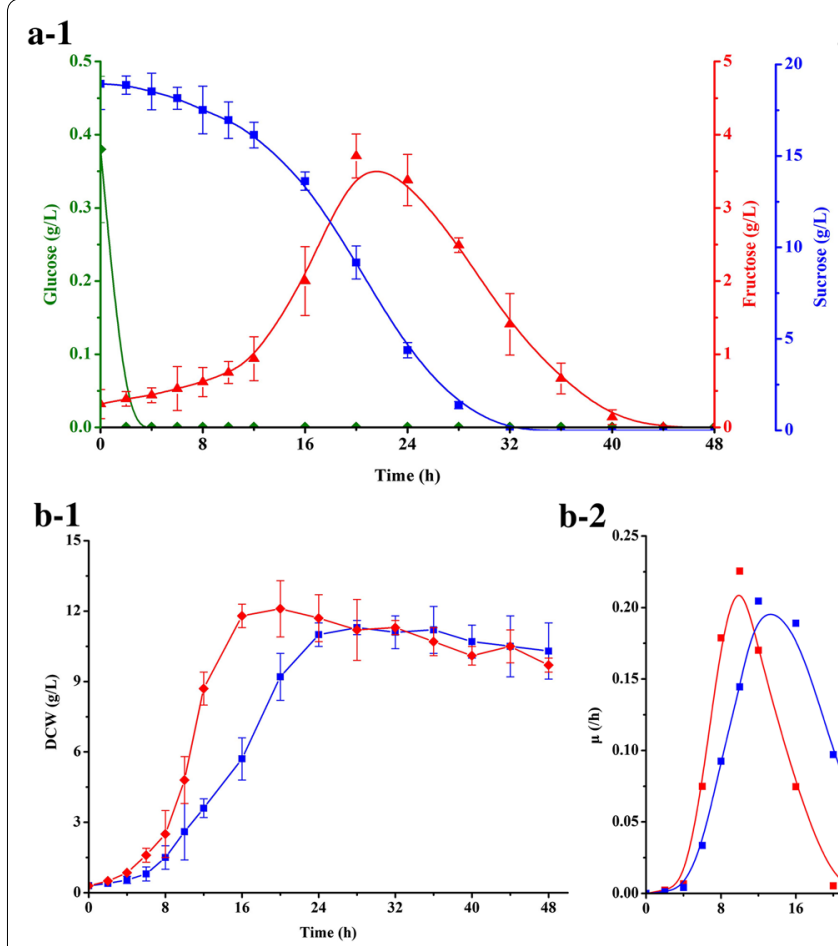

a-2
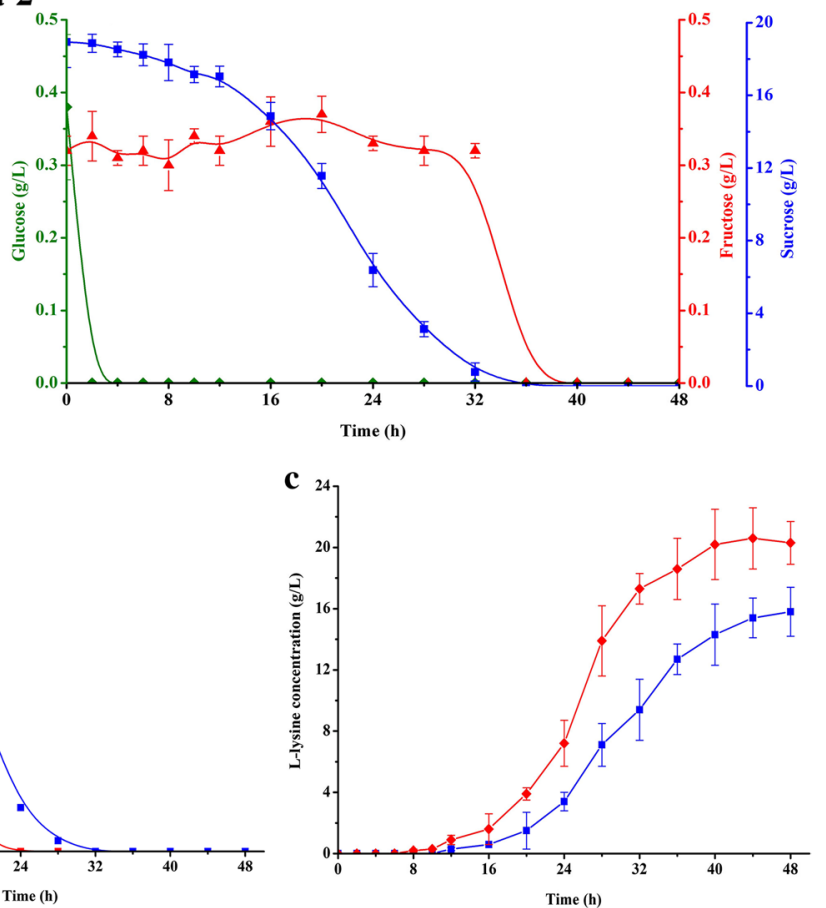

Fig. 1 Effect of hetero-expression of fructokinase-coding gene in C. glutamicum on glucose (filled diamond, green lines), fructose (filled triangle, red lines) and sucrose (filled square, blue lines) consumption in CgXIIP-medium (a), and on cell growth (b) and L-lysine production (c). a-1 Indicates strain K-1 and $\mathbf{a}-2$ indicates strain K-2. b, c Filled square and blue lines indicate strain K-1, whereas filled diamond and red lines indicate strain K-2. The data represent mean values and standard deviations obtained from two independent cultivations

K-4 were increased by 1.9 times, 19.8 times and $\sim 2.3$ times as compared with strain $\mathrm{K}-3$ on $\mathrm{CgXII}^{\mathrm{IP}}$-medium with glucose as sole carbon source, respectively (Table 1 ). The similar positive results were also found in fructose (increased by 3.6 times, 17.1 times and $\sim 5.7$ times, respectively), whereas the increase of cell growth and sugar consumption rate was not obvious on sucrose and molasses (Table 1). These results indicated that IolT1 and IolT2 participate in the uptake of glucose and fructose, which were consistent with previous reports [21, 22]. Interestingly, this was also linked to an increase in the activity of PEP carboxylase (PPC) and pyruvate kinase (PYK) (Table 2). PPC catalyzes the biosynthesis of oxaloacetate from PEP, and PYK catalyzes the biosynthesis of pyruvate from PEP (Fig. 3) [1]. IGS turned away from PEP to phosphorylate carbohydrate, resulting in that a large amount of intracellular PEP can be used as substrate for PPC and PYK [14]. However, although the productivity of strain K-4 was improved as compared with strain K-3, it was lower than that of strain K-2 with glucose as sole carbon source (Table 1). Lindner et al. indicated that glucokinase must be required in PTS-independent glucose uptake system to phosphorylate glucose [24]. However, glucokinase from C. glutamicum shows the low affinity for glucose with $K_{\mathrm{m}}$ values of $1.0 \mathrm{mmol} / \mathrm{L}$ [40]. In addition, many studies have demonstrated that it is necessary to co-overexpression of glucokinase to get the most out of IGS $[20,22]$, indicating that the expression level of glucokinase-coding gene was low in $C$. glutamicum.

Glucokinase catalyzes the phosphorylation of glucose to glucose-6-phosphate using ATP, ADP or inorganic polyphosphates (PolyP) as phosphoryl donor [19, 41]. C. glutamicum has two types of glucokinases, i.e., $\mathrm{GlK}_{\mathrm{Cg}}$ (ATP-dependent enzyme; ATP-GIK, encoded by $g l k_{\mathrm{Cg}}$ ) and polyphosphate-glucose phosphotransferases (PolyP/ ATP-dependent enzyme; PpgK, encoded by $p p g K$ ) [19], but PpgK plays a chief part in phosphorylation of glucose [40]. However, PpgK shows a low affinity for glucose with $K_{\mathrm{m}}$ values of $1.0 \mathrm{mmol} / \mathrm{L}$ [40]. In order to increase the glucose consumption of strain $\mathrm{K}-4$, the native $\mathrm{GlK}_{\mathrm{Cg}}$ was replaced by GlK from Bacillus subtilis 168 (i.e., $\mathrm{GlK}_{\mathrm{Bs}}$ ) with a high affinity for glucose $\left(K_{\mathrm{m}}=0.24 \mathrm{mmol} / \mathrm{L}\right)$ [42]. In addition, the strong tuf promoter was located at the front of $\mathrm{GlK}_{\mathrm{Bs}}$-coding gene $g l k_{\mathrm{Bs}}$. The resulting strain K-5 exhibited significantly increased glucose consumption rate, cell growth and L-lysine production as compared with strain K-4 (Table 1). The final production of L-lysine 


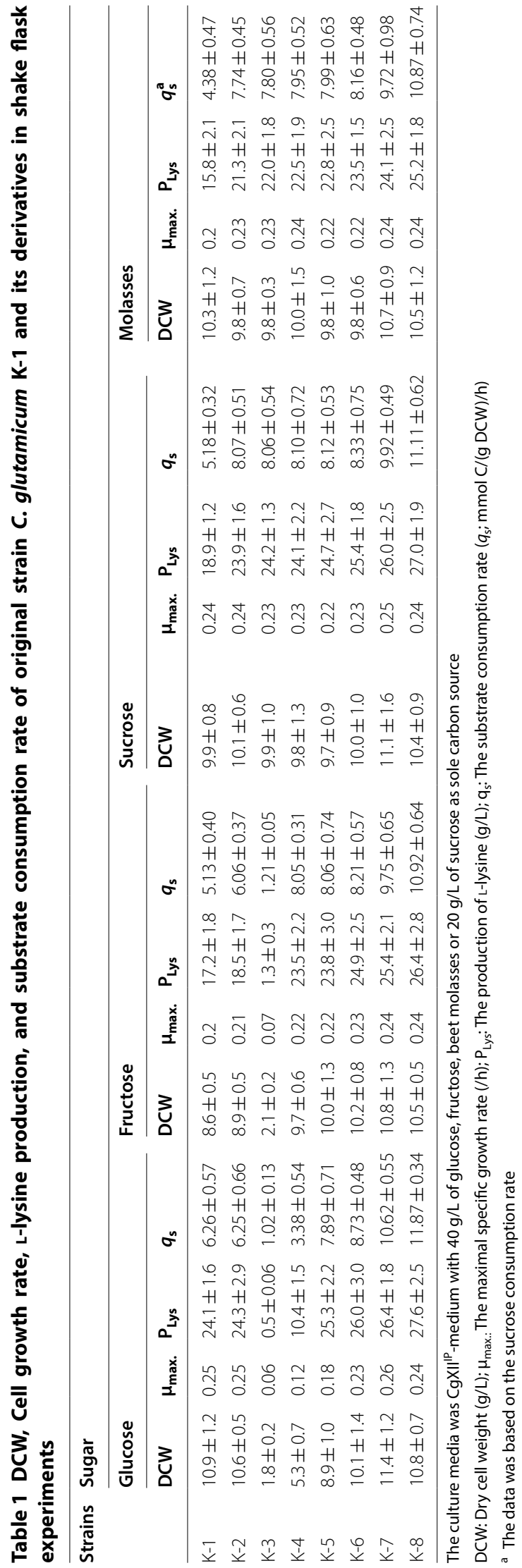



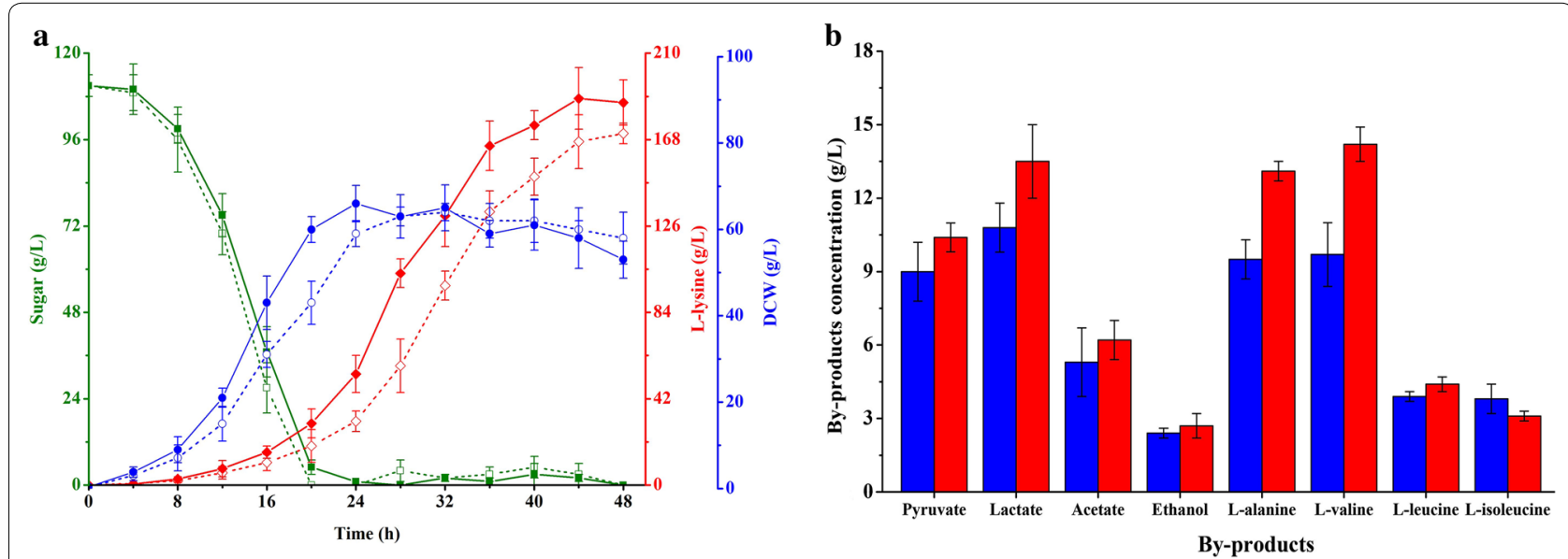

Fig. 2 Comparison of cell growth (filled circle, blue lines), substrate consumption (filled square, green lines) and L-lysine production (filled diamond, red lines) (a), and by-products accumulation (b) of different C. glutamicum strains in fed-batch fermentation. Signals denote: Strain K-1 (dotted lines or blue bars) and strain K-2 (full lines or red bars). The data represent mean values and standard deviations obtained from three independent cultivations

by strain $\mathrm{K}-5$ was $25.3 \pm 2.2 \mathrm{~g} / \mathrm{L}(0.63 \mathrm{~g} / \mathrm{g}$ glucose), which is $143.3 \%$ and $4.1 \%$ higher than that of strain $\mathrm{K}-4$ and $\mathrm{K}-2$, respectively. This advantage was also found in the fed-batch fermentation (Fig. 4). In the fed-batch fermentation, the L-lysine production of strain $\mathrm{K}-5$ reached to $209.0 \pm 21.6 \mathrm{~g} / \mathrm{L}$, which was $11.6 \%$ higher than that of strain K-2 (Fig. 4c). Although most of the test by-products in strain K-5 were reduced, the accumulation of acetate and ethanol was significantly increased as compared with strain K-2 (Fig. 4d). In addition, the intracellular NADH and ATP levels were decreased in strain K-5 (Table 3). ScrK and $\mathrm{GlK}_{\mathrm{Bs}}$ catalyze the phosphorylation of fructose and glucose to fructose-6-phosphate and glucose-6-phosphate using ATP as phosphoryl donor, respectively $[39,42]$. Introduction of ScrK and $\mathrm{GlK}_{\mathrm{Bs}}$ in strain K-5 could increase ATP consumption rate, thus perturbing the intracellular ATP balance. NADH can be oxidized to generate ATP [43], thereby meeting the demand of cell for ATP. It should be noted that the biosynthesis of acetate and ethanol involved in ATP and NADH regeneration (Fig. 3). This might be the reason why acetate and ethanol were significantly increased in strain K-5. Consistent with the previous results [44], the shortage of ATP has significantly impact on cell growth (Table 1 and Fig. 4a). To overcome this defect, the availability of ATP should be increased by reducing the consumption of ATP or/and by increasing ATP regeneration.

Lately, ADP-dependent glucokinase (i.e., ADP-GIK) was discovered in Archaea and Mammalian, which used ADP as phosphoryl donor for the phosphorylation of glucose $[45,46]$. In Methanococcus maripaludis, a bifunctional enzyme (i.e., ADP-GlK/PFK) with ability to phosphorylate glucose and fructose-6-phosphate has been reported [47]. In order to reducing the consumption of ATP, we introduced ADP-GIK/PFK from $M$. maripaludis into strain K-5. The resulting strain K-6 showed good properties in glucose consumption rate, cell growth, L-lysine production and by-products accumulation either in shake-flasks or in fed-batch fermentation as compared with strain K-5 (Table 1 and Fig. 4). Moreover, the intracellular NADH and ATP levels in strain K-6 were slightly higher than that of strain K-5 (Table 3), and this may be why strain K- 6 showed the better cell growth and the lower accumulation of by-products than that of strain K-5 (Fig. 4a, d). ADP-GIK/PFK catalyzed the phosphorylation of glucose with ADP as phosphoryl donor rather than ATP [47], thus avoiding over-utilizing ATP in carbohydrate uptake. Interestingly, the activity of PYK was increased by $25 \%$ as compared with strain K-5 (Table 2). This may be because PYK is activated by AMP [48], while AMP will be synthesized from ADP in the ADP-GIK/ PFK-catalyzed reactions (Fig. 3). Compared with strain K-2, however, strain K-6 exhibited the decreased intracellular NADH and ATP levels (Table 3), thereby hampering the cell growth and increasing the accumulation of acetate and ethanol (Fig. 4). The formation of acetate and ethanol involved in NADH and ATP regeneration (Fig. 3), thus making as much ATP for cell as possible.

\section{Overexpression of the NDH-2 benefits the further increase in carbohydrates consumption in PTS ${ }^{\text {Gic }}$. and PTS ${ }^{\mathrm{Fru}}$-deficient strains}

Compared with strain $\mathrm{K}-1$, the L-lysine production was drastically increased in fed-batch fermentation (from 


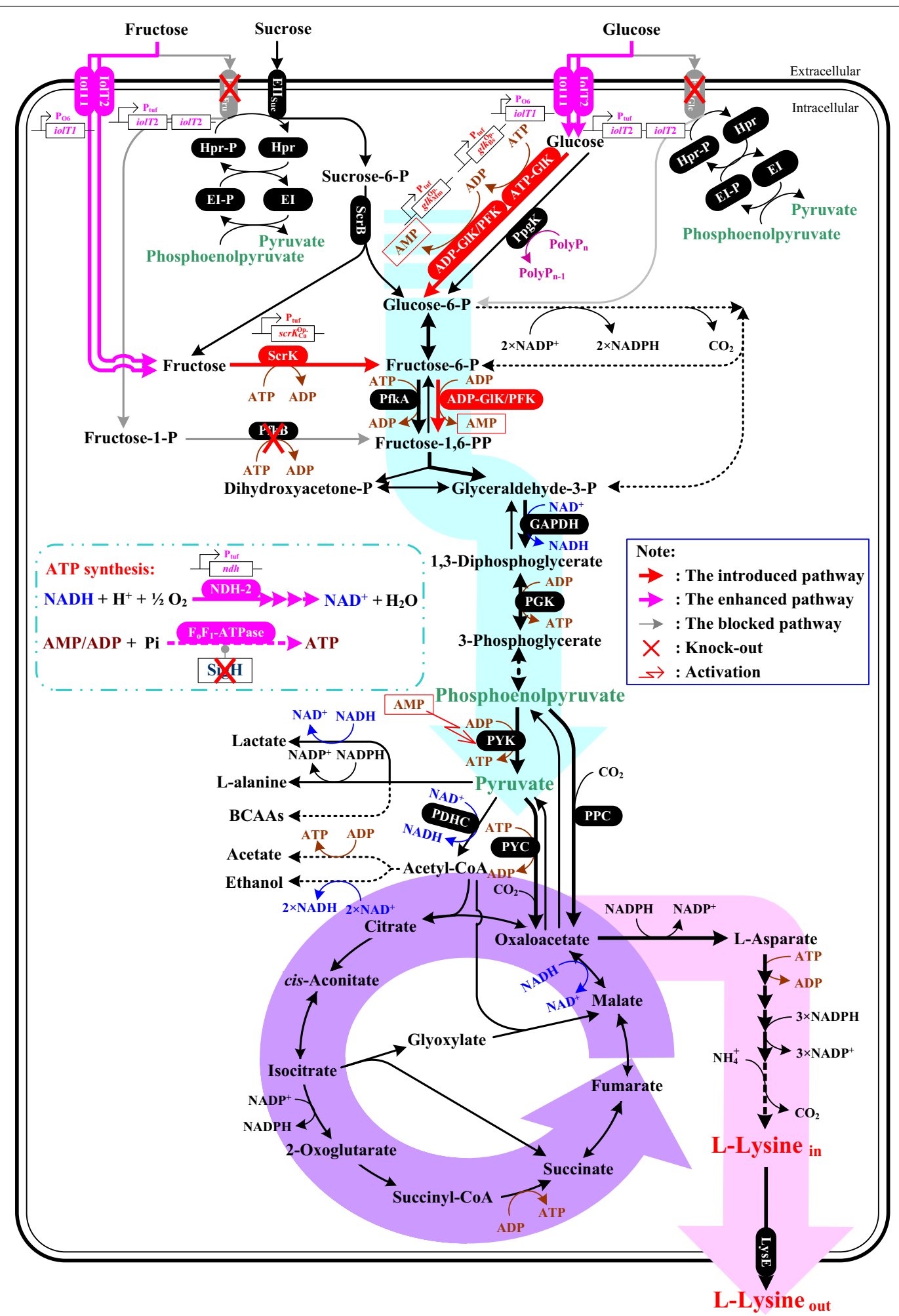

Fig. 3 Schematic representation of L-lysine biosynthesis pathway and variant pathways for uptake of glucose, fructose and sucrose in C. glutamicum. Red lines indicate the introduced exogenous pathway. Pink lines indicate the strengthened endogenous pathway. " $X$ " indicates gene deletion. ScrB: Sucrose-6-phosphate hydrolase, ScrK: Fructokinase, GIK: Glucokinase, PFK: Phosphofructokinase, GAPDH: Glyceraldehyde-3-phosphate dehydrogenase, PGK: Phosphoglycerate kinase, PYK: Pyruvate kinase, PYC: Pyruvate carboxylase, PPC: Phosphoenolpyruvate carboxylase, NDH-2: NADH dehydrogenase, Op. Optimized 


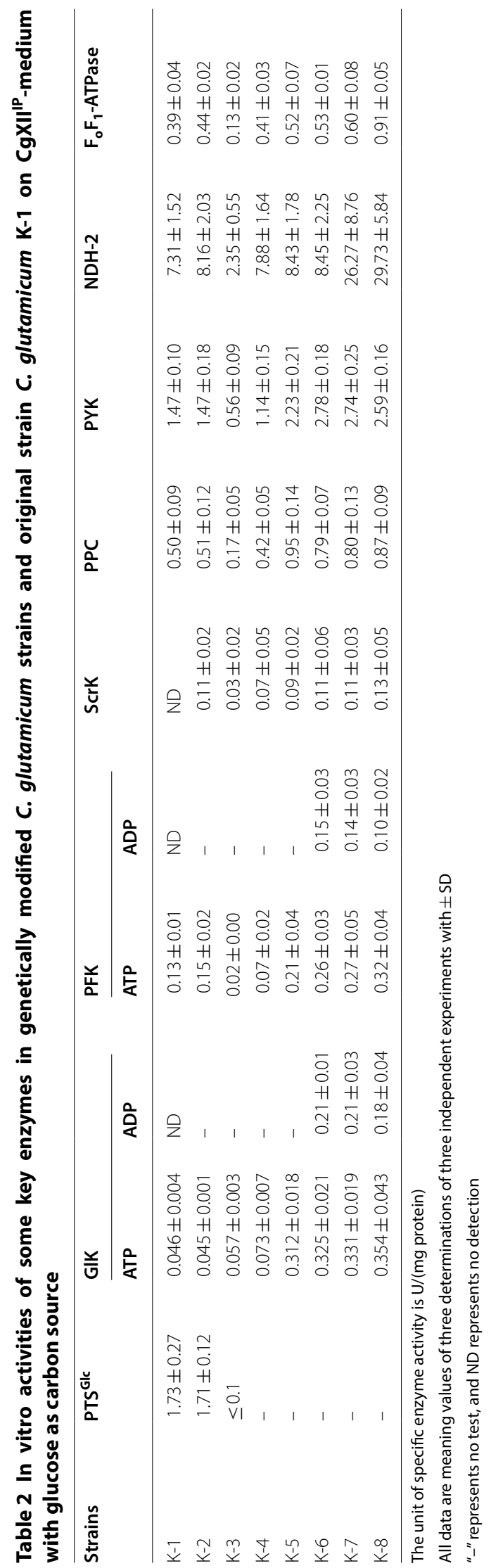


a
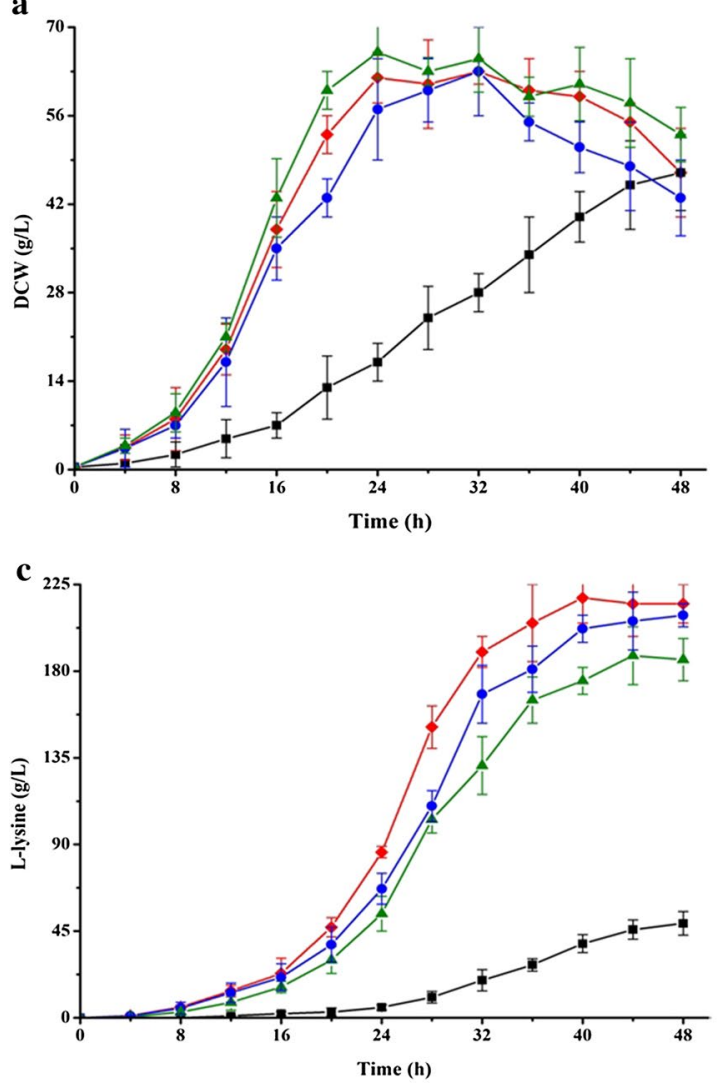

b

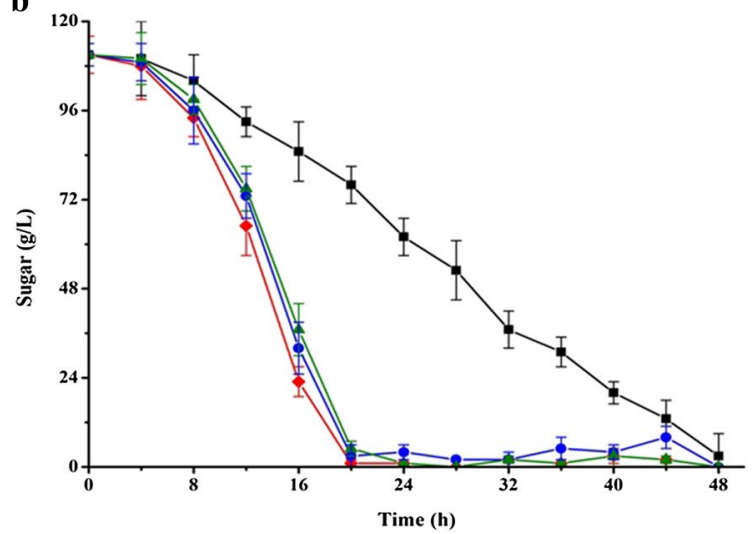

d

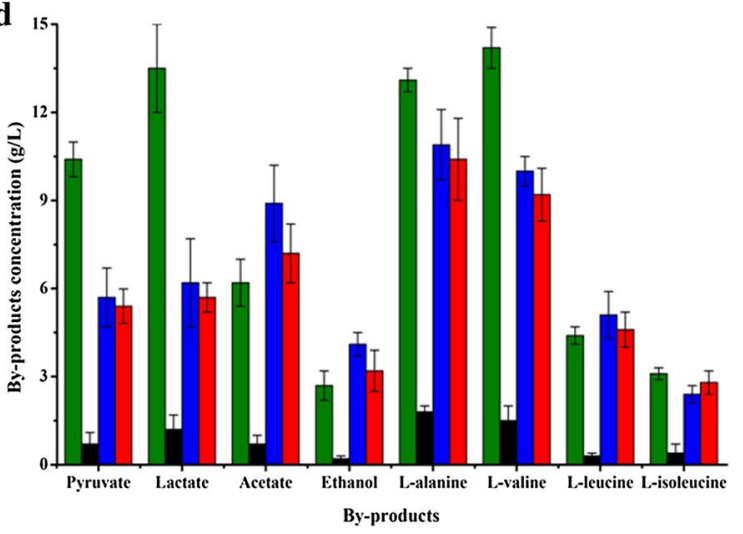

Fig. 4 Comparison of cell growth (a), substrate consumption (b) and L-lysine production (c), and by-products accumulations (d) of strains K-2, K-4, K-5 and K-6 in fed-batch fermentation. Signals denote: Strain K-2 (filled triangle, green lines or bars), strain K-4 (filled square, black lines or bars), strain K-5 (filled circle, blue lines or bars) and strain K-6 (filled diamond, red lines or bars). The data represent mean values and standard deviations obtained from three independent cultivations

$171.8 \pm 5.6 \mathrm{~g} / \mathrm{L}$ to $215.2 \pm 10.3 \mathrm{~g} / \mathrm{L})$, whereas the cell growth was markedly disturbed in strain K-6 because of the insufficient of ATP (Figs. 2a, 4a, c and Table 3). These results indicated that ATP may be a limiting factor for further increasing the production efficiency of L-lysine in strain K-6. ATP can be synthesized either by substrate level phosphorylation (SLP) or by electron transport phosphorylation (ETP) [44]. ETP, also known as oxidative phosphorylation, involved in the transfer of electrons from NADH to oxygen and the phosphorylation of AMP/ADP to synthesize ATP (Fig. 3) [49]. NADH dehydrogenase from C. glutamicum (i.e., NDH-2, encoded by $n d h$ gene) is a quinone-dependent dehydrogenase, which links with the inner layer of the cytoplasmic membrane [49]. To enhance ATP synthesis by ETP, the promoter of $n d h$ was substitute by the strong $t u f$ promoter in this study. Consistent with the previous results [50], $\mathrm{NADH} / \mathrm{NAD}^{+}$ratio in the resulting strain $C$. glutamicum K-7 was significantly decreased as compared with strain K-6 (from $0.20 \pm 0.02$ to $0.11 \pm 0.03$; Table 3 ). As expected, the glucose consumption rate in shakeflasks increased from $8.73 \pm 0.48(\mathrm{mmol} \mathrm{C}) /(\mathrm{g} \mathrm{DCW}) / \mathrm{h}$ in strain K-6 to $10.62 \pm 0.55(\mathrm{mmol} \mathrm{C}) /(\mathrm{g} \mathrm{DCW}) / \mathrm{h}$ in strain K-7 (Table 1). In addition, the other substrates (i.e., fructose, sucrose and molasses) consumption rate was also increased during overexpression of NDH-2 in strain K-6 (Table 1). The research has shown clearly that high level of $\mathrm{NADH} / \mathrm{NAD}^{+}$ratio inhibits the activity of glyceraldehyde-3-phosphate dehydrogenase (GAPDH) and pyruvate dehydrogenase (PDHC), which are the ratelimiting enzymes in glycolysis [51]. Therefore, the effect of overexpression of NDH-2 on increasing substrate consumption rate was likely due to the increased activity of GAPDH and PDHC in C. glutamicum. Consistent with the previous results [52], however, the intracellular ATP levels in strain K-7 were slightly higher than that of strain K-6 (Table 3), and the L-lysine production was not obviously increased in strain K-7 (Table 1 and Fig. 5c). 
Table 3 Comparison of intracellular nucleotides concentrations in original strain and the genetically defined $C$. glutamicum strains ( $\mu \mathrm{mol} /(\mathrm{g} \mathrm{DCW})$ )

\begin{tabular}{|c|c|c|c|c|c|c|c|}
\hline Strains & NADH & $\mathrm{NAD}^{+}$ & NADH/NAD ${ }^{+}$ & NADPH & NADP $^{+}$ & NADPH/NADP ${ }^{+}$ & ATP \\
\hline $\mathrm{K}-1$ & $1.69 \pm 0.22$ & $7.68 \pm 0.83$ & $0.22 \pm 0.03$ & $1.71 \pm 0.12$ & $1.47 \pm 0.15$ & $1.16 \pm 0.10$ & $4.98 \pm 0.42$ \\
\hline $\mathrm{K}-2$ & $1.67 \pm 0.23$ & $7.59 \pm 0.66$ & $0.22 \pm 0.01$ & $1.74 \pm 0.21$ & $1.42 \pm 0.19$ & $1.23 \pm 0.13$ & $4.87 \pm 0.53$ \\
\hline $\mathrm{K}-3$ & $0.28 \pm 0.02$ & $2.02 \pm 0.24$ & $0.14 \pm 0.02$ & $0.25 \pm 0.04$ & $0.30 \pm 007$ & $0.82 \pm 0.09$ & $0.98 \pm 0.13$ \\
\hline $\mathrm{K}-4$ & $1.03 \pm 0.15$ & $5.42 \pm 0.78$ & $0.19 \pm 0.03$ & $0.99 \pm 0.17$ & $0.94 \pm 0.12$ & $1.05 \pm 0.14$ & $2.68 \pm 0.19$ \\
\hline $\mathrm{K}-5$ & $1.51 \pm 0.18$ & $7.57 \pm 0.81$ & $0.20 \pm 0.01$ & $1.57 \pm 0.11$ & $1.38 \pm 0.15$ & $1.14 \pm 0.13$ & $2.92 \pm 0.35$ \\
\hline $\mathrm{K}-6$ & $1.54 \pm 0.22$ & $7.69 \pm 0.83$ & $0.20 \pm 0.02$ & $1.48 \pm 0.18$ & $1.31 \pm 0.16$ & $1.13 \pm 0.10$ & $3.08 \pm 0.32$ \\
\hline $\mathrm{K}-7$ & $0.93 \pm 0.23$ & $8.58 \pm 0.67$ & $0.11 \pm 0.03$ & $1.41 \pm 0.12$ & $1.25 \pm 0.13$ & $1.13 \pm 0.21$ & $3.43 \pm 0.45$ \\
\hline $\mathrm{K}-8$ & $0.98 \pm 0.22$ & $8.91 \pm 0.79$ & $0.11 \pm 0.01$ & $1.16 \pm 0.14$ & $1.05 \pm 0.10$ & $1.10 \pm 0.08$ & $4.69 \pm 0.47$ \\
\hline
\end{tabular}

Exponentially growing cells cultured in $\mathrm{CgXII}^{\mathrm{IP}}$ with $40 \mathrm{~g} / \mathrm{L}$ glucose as sole carbon source in shake flasks were used for analysis

All data are meaning values of three determinations of three independent experiments with $\pm S D$

In contrast, strain K-7 accumulated a large amount of by-products, especially pyruvate, acetate, $\mathrm{L}$-alanine and L-valine (Fig. 5d). This is presumably due to impairment of the intracellular NADH/NAD ${ }^{+}$balance for L-lysine production and hence resulting in increasing the byproducts biosynthetic pathway to regenerate NADH and ATP. In addition, overflow metabolism could be another reason for by-products accumulation [13]. As can be seen from Table 3, a large amount of pyruvate accumulated in the cell instead of entering into L-lysine biosynthetic pathway.

\section{Deletion of the sigH gene decreases the accumulation of by-products in C. glutamicum strain}

Base on the chemiosmotic theory of energy coupling, the synthesis of ATP from ETP involved in energy release by transfer of electrons from NADH to oxygen and energy transfer by phosphorylation of AMP/ADP [53]. $\mathrm{F}_{\mathrm{O}} \mathrm{F}_{1}$-ATPase catalyzed the formation of ATP (i.e., the phosphorylation of AMP/ADP) by proton motive force (pmf) [44]. Although $\mathrm{F}_{\mathrm{O}} \mathrm{F}_{1}$-ATPase was not essential for growth of C. glutamicum on glucose, inactivation of $\mathrm{F}_{\mathrm{O}} \mathrm{F}_{1}$-ATPase decreased the specific glucose uptake rate and mRNA levels of genes involved in amino acid biosynthesis [44]. Therefore, it is a useful strategy for increasing L-lysine production by genetically modifying $\mathrm{F}_{\mathrm{O}} \mathrm{F}_{1}$-ATPase. We tried to increase the expression level of $\mathrm{F}_{\mathrm{O}} \mathrm{F}_{1}$-ATPase by overexpression of $\mathrm{F}_{\mathrm{O}} \mathrm{F}_{1}$-ATPase-coding gene, but it was not successful as there were eight subunits of $\mathrm{F}_{\mathrm{O}} \mathrm{F}_{1}$-ATPase (encoded by atpBEFHAGDC) [44] (data not shown). As described by Barriuso-Iglesias et al. [54], $\mathrm{F}_{\mathrm{O}} \mathrm{F}_{1}$-ATPase-coding gene was expressed at $\mathrm{pH}$ 9.0 because it is regulated by SigmaH factor (i.e., SigH). However, the optical $\mathrm{pH}$ of $C$. glutamicum in L-lysine fermentation process is neutral $\mathrm{pH}$ (i.e., $\mathrm{pH} \approx 7.0$ ). In order to increase the expression level of $\mathrm{F}_{\mathrm{O}} \mathrm{F}_{1}$-ATPase-coding gene at neutral $\mathrm{pH}$, we deleted $\mathrm{SigH}$-coding gene sigH to construct a SigH-deficient strain C. glutamicum K-8. Consistent with previous results [54], the expression level of $\operatorname{atpB}$ was increased (increased by about 4.3 times), whereas the expression level of $\operatorname{sig} H$ was disappeared in strain $\mathrm{K}-8$ as compared with strain $\mathrm{K}-7$ at $\mathrm{pH}=7$ (Additional file 1: Fig. S2). Conversely, the expression level of atpB in strain K-8 was lower than that of strain $\mathrm{K}-7$ at $\mathrm{pH}=9$ (Additional file 1: Fig. S2). These results showed that deletion of SigH increased the activity of $\mathrm{F}_{\mathrm{O}} \mathrm{F}_{1}$-ATPase at neutral $\mathrm{pH}$ (Table 2). We also observed that the increased L-lysine production rate was induced by elevating ATP supply from ETP (Table 1 and Table 3). In other words, the more ATP is available in the cytosol, the more carbon flux will be entered into L-lysine biosynthetic pathway (Fig. 5). Previous researches have pointed out that interdiction of ATP regeneration from ETP decreased the specific glucose uptake rate in $C$. glutamicum [44, 55]. Our study again confirmed these viewpoints that strain K-8 showed the best substrate consumption rate among the test strains (Table 1). The titer of L-lysine reached $221.3 \pm 17.6 \mathrm{~g} / \mathrm{L}$ at a productivity of $5.53 \mathrm{~g} / \mathrm{L} / \mathrm{h}$ and a carbon yield of $0.71 \mathrm{~g} / \mathrm{g}$ glucose at $40 \mathrm{~h}$ (Fig. 5c). Those are the highest value for L-lysine production in fed-batch fermentation (Table 4), demonstrating that this engineered C. glutamicum strain is a competitive platform strain for L-lysine production.

\section{Conclusions}

For the first time, metabolic engineering of carbohydrate metabolism systems was identified as a critical factor for efficiently producing L-lysine from mixed sugar in C. glutamicum. The carbohydrate uptake system of strain was reconstructed and the intracellular ATP was complemented by enhancing ETP. We showed that hetero-expression of ScrK and introduction of optimized non-PTS were effective for increasing substrate consumption rate and L-lysine production from mixed 

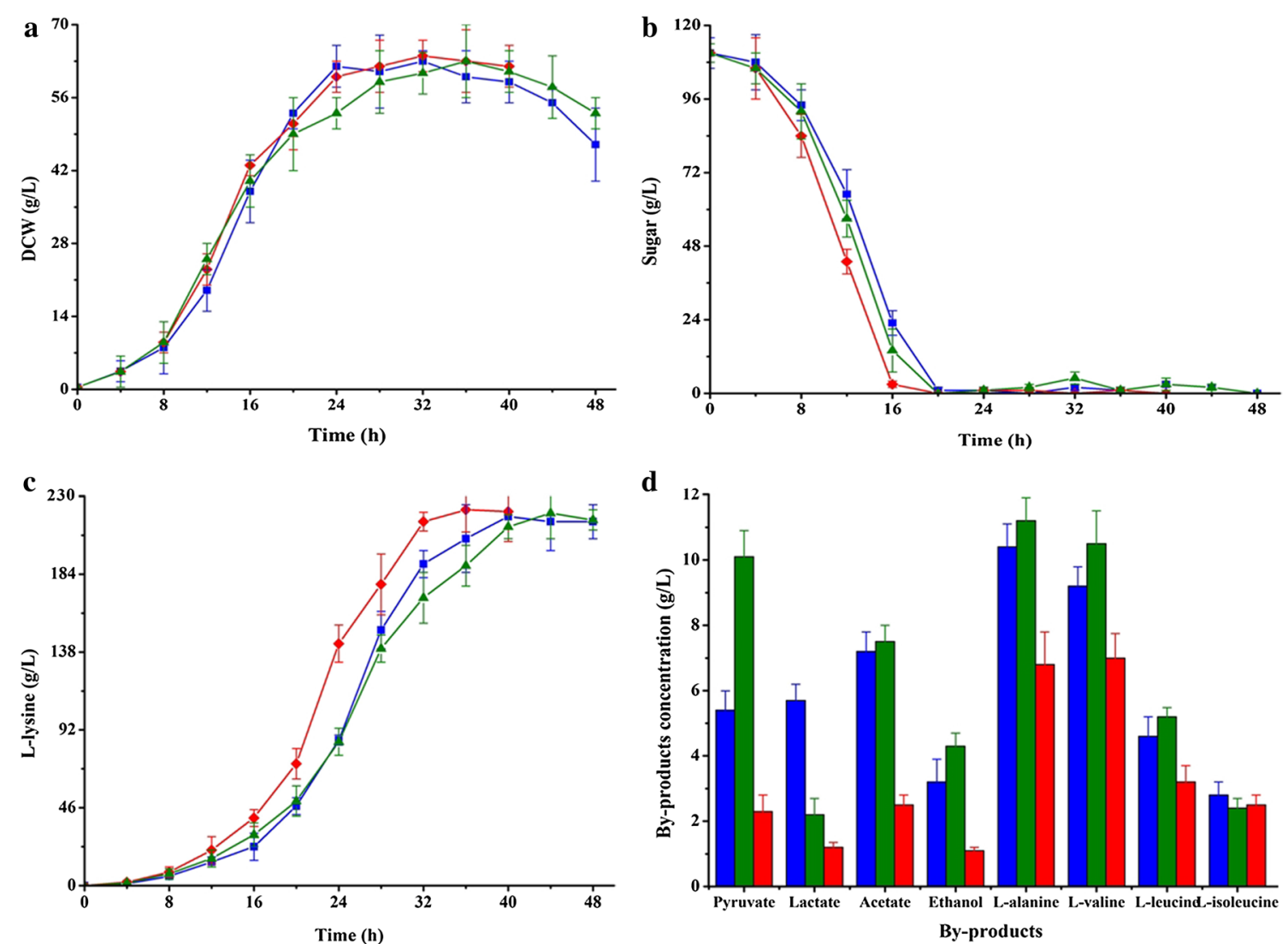

Fig. 5 Comparison of cell growth (a), substrate consumption (b) and L-lysine production (c), and by-products accumulations (d) of strains K-6, K-7 and K-8 in fed-batch fermentation. Signals denote: Strain K-6 (filled square, blue lines or bars), strain K-7 (filled triangle, green lines or bars) and strain K-8 (filled diamond, red lines or bars). The data represent mean values and standard deviations obtained from three independent cultivations

sugar. Furthermore, substitution of the promoter of $n d h$ by strong tuf promoter and deletion of the transcriptional regulator SigH further increased the L-lysine production and the highest substrate consumption rate, and these provided an efficient strategy for improving the efficiency of L-lysine production. The target strain K-8 produced $221.3 \pm 17.6 \mathrm{~g} / \mathrm{L}$ at a productivity of $5.53 \mathrm{~g} / \mathrm{L} / \mathrm{h}$ and a carbon yield of $0.71 \mathrm{~g} / \mathrm{g}$ glucose in fed-batch fermentation. To the best of our knowledge, those are the highest value for L-lysine production by fed-batch fermentation in the references.

However, this yield of $\mathrm{L}$-lysine in strain $\mathrm{K}-8$ is still lower than the theoretical level (i.e., $0.81 \mathrm{~g} / \mathrm{g}$ glucose). Thus, there is still plenty of room to enhance the yield of L-lysine. The most important by-product of strain K8 was pyruvate-family amino acids. Although adequate ATP could be used for pyruvic carboxylase (PYC) as cofactor, the activity of PYC was inhibited by L-aspartate [56]. Further improvement may be achieved by increasing the activity of PYC, for example, by overexpression of PYCcoding gene $p y c$ or by site-specific mutagenesis of $p y c$ to relieve feedback inhibition. Another potential strategy is to reduce the flux into biosynthetic pathway of pyruvatefamily amino acids. In addition, intracellular NADPH plays an important role in L-lysine production [1]. Therefore, how to effectively improve availability of intracellular NADPH is an important problem to be solved in further improving L-lysine production strains.

\section{Methods}

Strains, growth medium and culture conditions

Strains used in this study are listed in Table 5. LuriaBertani (LB) broth and LBG broth (LB supplemented with $5 \mathrm{~g} / \mathrm{L}$ glucose) were used for Escherichia coli and C. glutamicum, respectively [57]. Epo medium, used for preparing electroporation-competent C. glutamicum cells, and LBHIS (LB, Brain Heart Infusion, and sorbitol) medium, used for obtaining recombinant strains, were prepared according to the description reported by van der Rest et al. [58]. C. glutamicum and E. coli were grown at $30{ }^{\circ} \mathrm{C}$ and $37{ }^{\circ} \mathrm{C}$, respectively. Appropriately, strains were incubated with $50 \mu \mathrm{g} / \mathrm{mL}$ of kanamycin $(\mathrm{Km})$, and 
Table 4 Overview on the production of L-lysine by metabolic engineered C. glutamicum

\begin{tabular}{|c|c|c|c|c|c|}
\hline Strains & Culturing methods & Final titers $(\mathbf{g} / \mathbf{L})$ & Productivity (g/L/h) & Yield (g/g glucose) & References \\
\hline \multirow[t]{2}{*}{$\mathrm{K}-8$} & Batch & 27.6 & 0.58 & 0.69 & This work \\
\hline & Fed-batch & 221.3 & 5.53 & 0.71 & This work \\
\hline AM03 & Batch & 27.7 & 0.46 & 0.35 & {$[60]$} \\
\hline ZL-92 & Fed-batch & 201.6 & 5.04 & 0.65 & {$[61]$} \\
\hline$J L-69 P_{\text {tac-M }} g d h$ & Fed-batch & 181.5 & 3.78 & 0.65 & [3] \\
\hline $\mathrm{JOV} 2-\mathrm{C7}^{\mathrm{a}}$ & Batch & 13.2 & 0.33 & 0.31 & {$[62]$} \\
\hline LYS-12 & Fed-batch & 120 & 4.0 & 0.55 & [10] \\
\hline MH20-22B leuA $^{\mathrm{a}, \mathrm{b}}$ & Batch & 21.6 & 0.3 & 0.22 & {$[63]$} \\
\hline
\end{tabular}

a Achieved in shake-flask fermentation

b Estimated from reference

$25 \mu \mathrm{g} / \mathrm{mL}$ of $\mathrm{Km}$ was used to obtain recombinant strains of C. glutamicum.

Batch cultivation in shake flasks was carried out as described previously by $\mathrm{Xu}$ et al. [57]. The improved CgXII-medium (CgXII medium supplied with $0.25 \mathrm{~g} / \mathrm{L}$ $\mathrm{L}$-methionine and $0.6 \mathrm{mg} / \mathrm{L}$ biotin; $\mathrm{CgXII}^{\mathrm{IP}}$ ) without carbon source was used as minimal medium for L-lysine production. The main culture was performed in triplicate using 500-mL Erlenmeyer flasks with $50 \mathrm{~mL}$ of $\mathrm{CgXII}^{\mathrm{IP}}$-medium containing $40 \mathrm{~g} / \mathrm{L}$ of glucose or $40 \mathrm{~g} / \mathrm{L}$ of beet molasses, which were designed as $\mathrm{CgXII}^{\mathrm{IP}} \mathrm{G}$-medium or $\mathrm{CgXIII}^{\mathrm{IP}} \mathrm{M}$-medium, respectively.

The fed-batch fermentations were carried out in a 1-L jar fermenter (BLBIO-1GC-4, Bailun BiTechnology Co. Ltd., Shanghai, China) containing $0.25 \mathrm{~L}$ of medium with an inoculum size of $10 \%$ $(\mathrm{v} / \mathrm{v})$. Inoculum was obtained from a seed culture at $\Delta \mathrm{OD}_{562}=0.45-0.50$ (at a dilution of 25 -fold). The seed medium was prepared according to the description reported by $\mathrm{Xu}$ et al. [3]. The fermentation medium contained (per liter): 80 g glucose, 40 g beet molasses, $30 \mathrm{~g}$ corn steep liquor, $50 \mathrm{~g}\left(\mathrm{NH}_{4}\right)_{2} \mathrm{SO}_{4}$, $1.5 \mathrm{~g} \mathrm{KH}_{2} \mathrm{SO}_{4}, 1.0 \mathrm{~g} \mathrm{MgSO}_{4} \cdot 7 \mathrm{H}_{2} \mathrm{O}, 0.02 \mathrm{~g} \mathrm{FeSO}_{4}, 0.02 \mathrm{~g}$ $\mathrm{MnSO}_{4}, 0.5 \mathrm{~g}$ L-methionine, $0.05 \mathrm{~g}$ glycine betaine, $2.4 \mathrm{mg}$ biotin (add in 4 portions), $400 \mu \mathrm{g}$ thiamine- $\mathrm{HCl}$ and $2 \mathrm{~mL}$ antifoam. The aeration rate, $\mathrm{pH}$, dissolved oxygen levels, and temperature were set as described by Becker et al. [10]. Feed solution contained (per liter) $400 \mathrm{~g}$ glucose, $100 \mathrm{~g}$ beet molasses, $40 \mathrm{~g}\left(\mathrm{NH}_{4}\right)_{2} \mathrm{SO}_{4}$, which prepared according to the description reported by Becker et al. [10] and was used to maintain glucose concentration at $5 \sim 10 \mathrm{~g} / \mathrm{L}$ by adjusting the feeding rate according to the glucose concentration observed every $4 \mathrm{~h}$. Both these media were adjusted to $\mathrm{pH} 7.0$ with ammonium hydroxide.

\section{Construction of $C$. glutamicum recombinant strains}

The plasmids and oligonucleotides used in this study are listed in Table 5 and Additional file 1: Table S1, respectively. The gene deletions and gene replacements were executed in C. glutamicum chromosome according to the published method [57]. The cassettes of ATP-GlK (from B. subtilis), ADP-GlK (from M. maripaludis) and fructokinase (ScrK; from C. acetobutylicum) with $P_{\text {tuf }}$ promoter, rrnBT1T2 terminator and $E c o$ RI endonuclease was optimized for expression in C. glutamicum and then synthetized by GENEWIZ (Suzhou), Inc. (Suzhou, China). The plasmid construction and transformation were performed according to the previous descriptions [57]. The recombinant plasmids were transferred into $C$. glutamicum competent cell by electroporation, and the recombinant strains were screened on according to the published method [58]. The DNA manipulations and build process of the recombinant strain are stated in Additional file 1.

\section{Quantification of intracellular $\mathrm{NAD}^{+} / \mathrm{NADH}, \mathrm{NADP}^{+} /$ NADPH and ATP}

The C. glutamicum strains were cultivated in CgXII ${ }^{\mathrm{IP}}$-medium containing $40 \mathrm{~g} / \mathrm{L}$ of glucose, and the logarithmic growth phase cells were used for analysis. The intracellular concentration of $\mathrm{NAD}^{+} / \mathrm{NADH}$, $\mathrm{NADP}^{+} / \mathrm{NADPH}$ and ATP were measured using $\mathrm{NAD}^{+} /$ $\mathrm{NADH}$ Quantification Colorimetric Kit, $\mathrm{NADP}^{+} /$ NADPH Quantification Colorimetric Kit and ATP Colorimetric/Fluorometric Assay Kit (BioVision, Inc., Milpitas, CA) according to the manufacturer's instructions, respectively.

\section{Analytical methods}

A sample was taken from shake flasks or fermenter every 2 or $4 \mathrm{~h}$. A half of sample was used to measure biomass using a spectrophotometer at $600 \mathrm{~nm}$ after an appropriate dilution. According to the previous description [57], 
Table 5 Strains used in this study

\begin{tabular}{|c|c|c|}
\hline Contents & Relevant characteristic(s) & References \\
\hline \multicolumn{3}{|l|}{ C. glutamicum strains } \\
\hline $\mathrm{K}-1$ & $\begin{array}{l}\text { C. glutamicum JL-6 } \triangle p c k:: p p c \Delta o d x:: p y c \Delta P 1 g / t A / P_{\text {tac-M }} \text { gdh, L-lysine-producing strain } \\
\text { derived from strain C. glutamicum ATCC13032 }\end{array}$ & [3] \\
\hline $\mathrm{K}-2$ & Derivative of strain K-1 with hetero-expression of scrK from C. acetobutylicum & This work \\
\hline K-3 & Derivative of strain $\mathrm{K}-2$ with deletion of $p t s \mathrm{G}$ and $p t s F$ & This work \\
\hline $\mathrm{K}-4$ & $\begin{array}{l}\text { Derivative of strain } \mathrm{K}-3 \text { with two point mutations in the promoter of iolT1, relative to } \\
\text { the start codon at position-113 }(\mathrm{A} \rightarrow \mathrm{G}) \text { and }-112(\mathrm{C} \rightarrow \mathrm{G}) \text { respectively, and with } \\
\text { replacement of natural promoter of gene iolT2 by tuf promoter as well as two } \\
\text { copies of iolT2 gene }\end{array}$ & This work \\
\hline K-5 & $\begin{array}{l}\text { Derivative of strain K-4 with replacement of natural gene } g / k_{C g} \text { by the optimized } \\
\text { gene } g / k_{B S} \text { from B. subtilis }\end{array}$ & This work \\
\hline K-6 & $\begin{array}{l}\text { Derivative of strain } \mathrm{K}-5 \text { with introduction of the optimized gene } g / k_{\mathrm{Mm}} \text { from } \mathrm{M} \text {. } \\
\text { maripaludis }\end{array}$ & This work \\
\hline K-7 & $\begin{array}{l}\text { Derivative of strain K-6 with replacement of natural promoter of gene ndh by tuf } \\
\text { promoter }\end{array}$ & This work \\
\hline $\mathrm{K}-8$ & Derivative of strain $\mathrm{K}-7$ with deletion of the gene $\mathrm{sigH}$ & This work \\
\hline \multicolumn{3}{|l|}{ Plasmids } \\
\hline pK18mobsacB & Integration vector & [59] \\
\hline pK18mobsacB/ApfkB::scrk & Integration vector for introduction of the cassette of scrK gene at pfkB gene loci & This work \\
\hline pK18mobsacB/AptsG & Integration vector for deletion of pts $G$ gene & This work \\
\hline pK18mobsacB/AptsF & Integration vector for deletion of ptsF gene & This work \\
\hline pK18mobsacB/AptsF::glk Op. & Integration vector for introduction of the cassette of $g / k_{\mathrm{Mm}}$ gene at $p t s F$ gene loci & This work \\
\hline 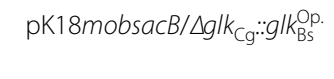 & $\begin{array}{l}\text { Integration vector for replacement of the native } g / k_{C g} \text { gene by the cassette of } g / k_{B s} \\
\text { gene }\end{array}$ & This work \\
\hline $\mathrm{pK} 18 \mathrm{mobsacB} / \mathrm{P}_{\mathrm{O} 6}$ iolT1 & $\begin{array}{l}\text { Integration vector for introducing two point mutations in the promoter region } \\
\text { of iolT1, relative to the start codon at position-113 }(A \rightarrow G) \text { and }-112(C \rightarrow G) \text {, } \\
\text { respectively }\end{array}$ & This work \\
\hline pK18mobsacB-P tuf $_{\text {iolT2 }}$ & $\begin{array}{l}\text { Integration vector for replacement of the nature promoter of iolT2 gene by the tuf } \\
\text { promoter }\end{array}$ & This work \\
\hline pK18mobsacB-2 $\times$ iolT2 & $\begin{array}{l}\text { Integration vector for introducing a second copy of the io/T2 gene with tuf pro- } \\
\text { moter }\end{array}$ & This work \\
\hline pK18mobsacB-P $P_{\text {tuf }} n d h$ & $\begin{array}{l}\text { Integration vector for replacement of the nature promoter of ndh gene by the tuf } \\
\text { promoter }\end{array}$ & This work \\
\hline pK18mobsacB/AsigH & Integration vector for deletion of sigH gene & This work \\
\hline
\end{tabular}

the correlation factor between dry cell weight (DCW) and $\mathrm{OD}_{600}$ was determined as $0.318\left(1 \mathrm{OD}_{600}=0.318 \mathrm{~g}\right.$ DCW). The other half of sample was diluted 100-fold, and then used to determine glucose and L-lysine concentration using an SBA-40E immobilized enzyme biosensor (Shandong, China). L-lysine concentration was determined as lysine. $\mathrm{HCl}$ in duplicates. In addition, the samples were also used to determine the concentration of sucrose, fructose and by-products (including amino acids and organic acids) by high performance liquid chromatography (HPLC) according to the description of Xu et al. [57]. The enzyme activity assay is stated in Additional file 1.

\section{Supplementary information}

Supplementary information accompanies this paper at https://doi. org/10.1186/s12934-020-1294-7.
Additional file 1. Oligonucleotides used in this study, mutation information of the genes ptsG, ptsl and pts $\mathrm{H}$ and strategy used for construction of recombinant plasmids.

\section{Abbreviations}

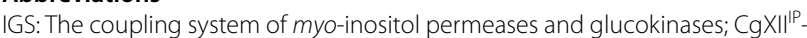
medium: The improved CgXII-medium; CgXII ${ }^{\mathbb{P} M-m e d i u m: ~} \mathrm{CgX \|} \|^{\mathbb{P}}$-medium with $40 \mathrm{~g} / \mathrm{L}$ of beet molasses.

\section{Acknowledgements}

We thank Dr. XL Chen from State Key Laboratory of Food Science and Technology at Jiangnan University for assistance in data analysis.

\section{Authors' contributions}

$J X, L L$ and WZ conceived and designed the experiments, HR and HY performed the experiments, LL and WZ analyzed the data, JX and HR wrote the paper. All authors read and approved the final manuscript.

\section{Funding}

This work was supported by the National Natural Science Foundation of China (Grant Number 31601459); the China Postdoctoral Science Foundation (Grant Number 2016M590410); and the Top-Notch Academic Programs Project 
of Jiangsu Higher Education Institutions, the 111 project (Grant Number 111-2-06).

\section{Availability of data and materials}

All data generated or analyzed during this study are included in this published article and the additional file. The authors are willing to provide any additional data and materials related to this research that may be requested for research purposes.

\section{Ethics approval and consent to participate Not applicable.}

\section{Consent for publication}

All authors give consent to publish the research in Microbial Cell Factories.

\section{Competing interests}

The authors declare that they have no competing interests.

\section{Author details}

${ }^{1}$ The Key Laboratory of Industrial Biotechnology, Ministry of Education, School of Biotechnology, Jiangnan University, 1800\# Lihu Road, Wuxi 214122, China.

${ }^{2}$ State Key Laboratory of Food Science and Technology, School of Biotechnology, Jiangnan University, 1800\# Lihu Road, Wuxi 214122, China.

Received: 19 November 2019 Accepted: 23 January 2020

Published online: 18 February 2020

\section{References}

1. Xu JZ, Yang HK, Zhang WG. NADPH metabolism: a survey of its theoretical characteristics and manipulation strategies in amino acid biosynthesis. Crit Rev Biotechnol. 2018;38:1061-76.

2. Sagong HY, Kim KJ. Structural basis for redox sensitivity in Corynebacterium glutamicum diaminopimelate epimerase: an enzyme involved in L-lysine biosynthesis. Sci Rep. 2017;7:42318.

3. Xu JZ, Wu ZH, Gao SJ, Zhang W. Rational modification of tricarboxylic acid cycle for improving L-lysine production in Corynebacterium glutamicum. Microb Cell Fact. 2018;17:105.

4. Becker J, Wittmann C. The L-lysine story: from metabolic pathways to industrial production. In: Wendisch VF, editor. Amino Acid Biosynthesis. Berlin: Springer; 2007. p. 32

5. Becker J, Rohles CM, Wittmann C. Metabolically engineered Corynebacterium glutamicum for bio-based production of chemicals, fuels, materials, and healthcare products. Metab Eng. 2018;50:122-41.

6. Becker J, Wittmann C. Bio-based production of chemicals, materials and fuels-Corynebacterium glutamicum as versatile cell factory. Curr Opin Biotechnol. 2012;23:631-40.

7. Xu J, Zhang J, Guo Y, Zai Y, Zhang W. Improvement of cell growth and L-lysine production by genetically modified Corynebacterium glutamicum during growth on molasses. J Ind Microbiol Biotechnol. 2013;40:1423-32.

8. Kelle R, Hermann T, Bathe B. L-lysine production. In: Eggeling L, Bott M, editors. Handbook of Corynebacterium glutamicum. Boca Raton: CRC Press; 2005

9. Mori M, Shiio I. Phosphoenolpyruvate: sugar phosphotransferase systems and sugar metabolism in Brevibacterium flavum. Agric Biol Chem. 1987:51:8.

10. Becker J, Zelder O, Hafner S, Schroder H, Wittmann C. From zero to hero-design-based systems metabolic engineering of Corynebacterium glutamicum for L-lysine production. Metab Eng. 2011;13:159-68.

11. Blombach B, Arndt A, Auchter M, Eikmanns BJ. L-valine production during growth of pyruvate dehydrogenase complex-deficient Corynebacterium glutamicum in the presence of ethanol or by inactivation of the transcriptional regulator SugR. Appl Environ Microbiol. 2009;75:1197-200.

12. Dominguez $\mathrm{H}$, CocaignBousquet $M$, Lindley ND. Simultaneous consumption of glucose and fructose from sugar mixtures during botch growth of Corynebacterium glutamicum. Appl Microbiol Biotechnol. 1997;47:600-3.

13. Lara AR, Caspeta L, Gosset G, Bolivar F, Ramirez OT. Utility of an Escherichia coli strain engineered in the substrate uptake system for improved culture performance at high glucose and cell concentrations: an alternative to fed-batch cultures. Biotechnol Bioeng. 2008;99:893-901.
14. Petersen S, Mack C, de Graaf AA, Riedel C, Eikmanns BJ, Sahm H. Metabolic consequences of altered phosphoenolpyruvate carboxykinase activity in Corynebacterium glutamicum reveal anaplerotic regulation mechanisms in vivo. Metab Eng. 2001;3:344-61.

15. Krings E, Krumbach K, Bathe B, Kelle R, Wendisch VF, Sahm H, Eggeling L. Characterization of myo-inositol utilization by Corynebacterium glutamicum: the stimulon, identification of transporters, and influence on L-lysine formation. J Bacteriol. 2006;188:8054-61.

16. Radek A, Tenhaef N, Muller MF, Brusseler C, Wiechert W, Marienhagen J, Polen T, Noack S. Miniaturized and automated adaptive laboratory evolution: evolving Corynebacterium glutamicum towards an improved d-xylose utilization. Bioresour Technol. 2017;245:1377-85.

17. Brusseler C, Radek A, Tenhaef N, Krumbach K, Noack S, Marienhagen J. The myo-inositol/proton symporter lolT1 contributes to D-xylose uptake in Corynebacterium glutamicum. Bioresour Technol. 2018;249:953-61.

18. Klaffl S, Brocker M, Kalinowski J, Eikmanns BJ, Bott M. Complex regulation of the phosphoenolpyruvate carboxykinase gene $p c k$ and characterization of its GntR-type regulator lolR as a repressor of myo-inositol utilization genes in Corynebacterium glutamicum. J Bacteriol. 2013;195:4283-96.

19. Lindner SN, Seibold GM, Henrich A, Kramer R, Wendisch VF. Phosphotransferase system-independent glucose utilization in corynebacterium glutamicum by inositol permeases and glucokinases. Appl Environ Microbiol. 2011;77:3571-81.

20. Perez-Garcia F, Peters-Wendisch P, Wendisch VF. Engineering Corynebacterium glutamicum for fast production of L-lysine and L-pipecolic acid. Appl Microbiol Biotechnol. 2016;100:8075-90.

21. Baumchen C, Krings E, Bringer S, Eggeling L, Sahm H. Myo-inositol facilitators loIT1 and lolT2 enhance D-mannitol formation from D-fructose in Corynebacterium glutamicum. FEMS Microbiol Lett. 2009;290:227-35.

22. Chen Z, Huang J, Wu Y, Wu W, Zhang Y, Liu D. Metabolic engineering of Corynebacterium glutamicum for the production of 3-hydroxypropionic acid from glucose and xylose. Metab Eng. 2017;39:151-8.

23. Ikeda M. Sugar transport systems in Corynebacterium glutamicum: features and applications to strain development. Appl Microbiol Biotechnol. 2012:96:1191-200.

24. Lindner SN, Seibold GM, Kramer R, Wendisch VF. Impact of a new glucose utilization pathway in amino acid-producing Corynebacterium glutamicum. Bioeng Bugs. 2011;2:291-5.

25. Shen PH, Han F, Su SQ, Zhang JY, Chen ZN, Li JF, Gan JY, Feng B, Wu B. Using pig manure to promote fermentation of sugarcane molasses alcohol wastewater and its effects on microbial community structure. Biores Technol. 2014;155:323-9.

26. Li KT, Peng WF, Zhou J, Wei SJ, Cheng X. Establishment of beet molasses as the fermentation substrate for industrial vitamin B-12 production by Pseudomonas denitrificans. J Chem Technol Biotechnol. 2013;88:1730-5.

27. Yin FW, Zhu SY, Guo DS, Ren LJ, Ji XJ, Huang H, Gao Z. Development of a strategy for the production of docosahexaenoic acid by Schizochytrium sp. from cane molasses and algae-residue. Bioresour Technol. 2019;271:118-24.

28. Bofo DCD, Cabral RAF, Andrietta SR, Telis-Romero J. Rheological behavior of molasses for application in industry. Environ Prog Sustain Energy. 2016;35:1545-52

29. Anaya-Reza O, Lopez-Arenas T. Comprehensive assessment of the L-lysine production process from fermentation of sugarcane molasses. Bioprocess Biosyst Eng. 2017:40:1033-48.

30. Shibukawa Mitsuru, Kurima Masao. Ohuchi S: L-glutamic acid fermentation with molasses. Agri Biol Chem. 1970;34:6.

31. Kong X, He A, Zhao J, Wu H, Jiang M. Efficient acetone-butanol-ethanol production (ABE) by Clostridium acetobutylicum XY16 immobilized on chemically modified sugarcane bagasse. Bioprocess Biosyst Eng. 2015;38:1365-72.

32. Becker J, Klopprogge C, Zelder O, Heinzle E, Wittmann C. Amplified expression of fructose 1,6-bisphosphatase in Corynebacterium glutamicum increases in vivo flux through the pentose phosphate pathway and lysine production on different carbon sources. Appl Environ Microbiol. 2005;71:8587-96.

33. Yamamoto S, Gunji W, Suzuki H, Toda H, Suda M, Jojima T, Inui M, Yukawa H. Overexpression of genes encoding glycolytic enzymes in Corynebacterium glutamicum enhances glucose metabolism and alanine production under oxygen deprivation conditions. Appl Environ Microbiol. 2012;78:4447-57. 
34. Sekine $H$, Shimada T, Hayashi $C$, Ishiguro A, Tomita F, Yokota A. $\mathrm{H}+$-ATPase defect in Corynebacterium glutamicum abolishes glutamic acid production with enhancement of glucose consumption rate. Appl Microbiol Biotechnol. 2001;57:534-40.

35. Blombach B, Seibold GM. Carbohydrate metabolism in Corynebacterium glutamicum and applications for the metabolic engineering of L-lysine production strains. Appl Microbiol Biotechnol. 2010;86:1313-22.

36. Peng $X$, Okai $N$, Vertes AA, Inatomi K, Inui M, Yukawa H. Characterization of the mannitol catabolic operon of Corynebacterium glutamicum. Appl Microbiol Biotechnol. 2011;91:1375-87.

37. Hoffmann SL, Jungmann L, Schiefelbein S, Peyriga L, Cahoreau E, Portais JC, Becker J, Wittmann C. Lysine production from the sugar alcohol mannitol: design of the cell factory Corynebacterium glutamicum SEA-3 through integrated analysis and engineering of metabolic pathway fluxes. Metab Eng. 2018;47:475-87.

38. Zhang XM, Yao LP, Xu GQ, Zhu JF, Zhang XJ, Shi JS, Xu ZH. Enhancement of fructose utilization from sucrose in the cell for improved L-serine production in engineered Corynebacterium glutamicum. Biochem Eng J. 2017;118:113-22.

39. Moon MW, Kim HJ, Oh TK, Shin CS, Lee JS, Kim SJ, Lee JK. Analyses of enzyme II gene mutants for sugar transport and heterologous expression of fructokinase gene in Corynebacterium glutamicum ATCC 13032. FEMS Microbiol Lett. 2005;244:259-66.

40. Lindner SN, Knebel S, Pallerla SR, Schoberth SM, Wendisch VF. Cg2091 encodes a polyphosphate/ATP-dependent glucokinase of Corynebacterium glutamicum. Appl Microbiol Biotechnol. 2010;87:703-13.

41. Ito S, Fushinobu S, Jeong JJ, Yoshioka I, Koga S, Shoun H, Wakagi T. Crystal structure of an ADP-dependent glucokinase from Pyrococcus furiosus: implications for a sugar-induced conformational change in ADP-dependent kinase. J Mol Biol. 2003;331:871-83.

42. Mesak LR, Mesak FM, Dahl MK. Bacillus subtilis GlcK activity requires cysteines within a motif that discriminates microbial glucokinases into two lineages. BMC Microbiol. 2004;4:6.

43. Becker M, Junghans L, Teleki A, Bechmann J, Takors R. Perfusion cultures require optimum respiratory ATP supply to maximize cell-specific and volumetric productivities. Biotechnol Bioeng. 2019;116(5):951-60.

44. Koch-Koerfges A, Kabus A, Ochrombel I, Marin K, Bott M. Physiology and global gene expression of a Corynebacterium glutamicum $\triangle F_{1} F_{O}$-ATP synthase mutant devoid of oxidative phosphorylation. Biochim Biophys Acta. 2012;1817(2):370-80.

45. Richter JP, Goroncy AK, Ronimus RS, Sutherland-Smith AJ. The structural and functional characterization of mammalian ADP-dependent glucokinase. J Biol Chem. 2016;291:3694-704.

46. Kengen SW, de Bok FA, van Loo ND, Dijkema C, Stams AJ, de Vos WM. Evidence for the operation of a novel Embden-Meyerhof pathway that involves ADP-dependent kinases during sugar fermentation by Pyrococcus furiosus. J Biol Chem. 1994;269:17537-41.

47. Castro-Fernandez V, Bravo-Moraga F, Herrera-Morande A, Guixe V. Bifunctional ADP-dependent phosphofructokinase/glucokinase activity in the order Methanococcales biochemical characterization of the mesophilic enzyme from Methanococcus maripaludis. FEBS J. 2014;281:2017-29.

48. Jetten MSM, Gubler ME, Lee SH, Sinskey AJ. Structural and functional analysis of pyruvate kinase from Corynebacterium glutamicum. Appl Environ Microbiol. 1994;60:2501-7.

49. Bott M, Niebisch $A$. The respiratory chain of Corynebacterium glutamicum. J Biotechnol. 2003;104:129-53.

50. Tsuge Y, Uematsu K, Yamamoto S, Suda M, Yukawa H, Inui M. Glucose consumption rate critically depends on redox state in Corynebacterium glutamicum under oxygen deprivation. Appl Microbiol Biotechnol. 2015:99:5573-82.
51. Dominguez H, Rollin C, Guyonvarch A, Guerquin-Kern JL, CocaignBousquet M. ND L: carbon-flux distribution in the central metabolic pathways of Corynebacterium glutamicum during growth on fructose. FEBS J. 2001;254:7.

52. Nantapong $N$, Kugimiya $Y$, Toyama H, Adachi O, Matsushita K. Effect of $\mathrm{NADH}$ dehydrogenase-disruption and over-expression on respirationrelated metabolism in Corynebacterium glutamicum KY9714. Appl Microbiol Biotechnol. 2004;66:187-93.

53. Nath S. Two-ion theory of energy coupling in ATP synthesis rectifies a fundamental flaw in the governing equations of the chemiosmotic theory. Biophys Chem. 2017;230:45-52.

54. Barriuso-Iglesias M, Barreiro C, Flechoso F, Martin JF. Transcriptional analysis of the FOF1 ATPase operon of Corynebacterium glutamicum ATCC 13032 reveals strong induction by alkaline $\mathrm{pH}$. Microbiology-SGM. 2006;152:11-21.

55. Koch-Koerfges A, Pfelzer N, Platzen L, Oldiges M, Bott M. Conversion of Corynebacterium glutamicum from an aerobic respiring to an aerobic fermenting bacterium by inactivation of the respiratory chain. Biochimica Et Biophysica Acta-Bioenergetics. 2013;1827:699-708.

56. Ohnishi J, Mitsuhashi S, Hayashi M, Ando S, Yokoi H, Ochiai K, Ikeda M. A novel methodology employing Corynebacterium glutamicum genome information to generate a new L-lysine-producing mutant. Appl Microbiol Biotechnol. 2002;58:217-23.

57. Xu JZ, Han M, Zhang JL, Guo YF, Zhang WG. Metabolic engineering Corynebacterium glutamicum for the L-lysine production by increasing the flux into L-lysine biosynthetic pathway. Amino Acids. 2014;46:2165-75.

58. van der Rest ME, Lange C, Molenaar D. A heat shock following electroporation induces highly efficient transformation of Corynebacterium glutamicum with xenogeneic plasmid DNA. Appl Microbiol Biotechnol. 1999;52:541-5.

59. Schafer A, Tauch A, Jager W, Kalinowski J, Thierbach G, Puhler A. Small mobilizable multipurpose cloning vectors derived from the Escherichia coli plasmids pK18 and pK19 - Selection of defined deletions in the chromosome of Corynebacterium glutamicum. Gene. 1994;145:69-73.

60. Wu WJ, Zhang Y, Liu DH, Chen Z. Efficient mining of natural NADHutilizing dehydrogenases enables systematic cofactor engineering of lysine synthesis pathway of Corynebacterium glutamicum. Metab Eng. 2019;52:77-86.

61. Xu JZ, Yu HB, Han M, Liu LM, Zhang WG. Metabolic engineering of glucose uptake systems in Corynebacterium glutamicum for improving the efciency of L-lysine production. J Ind Microbiol Biotechnol. 2019:46:937-49.

62. van Ooyen J, Noack S, Bott M, Reth A, Eggeling L. Improved L-lysine production with Corynebacterium glutamicum and systemic insight into citrate synthase fux and activity. Biotechnol Bioeng. 2012;109:2070-81.

63. Sindelar G, Wendisch VF. Improving lysine production by Corynebacterium glutamicum through DNA microarray-based identifcation of novel target genes. Appl Microbiol Biotechnol. 2007;76:677-89.

\section{Publisher's Note}

Springer Nature remains neutral with regard to jurisdictional claims in published maps and institutional affiliations.

Ready to submit your research? Choose BMC and benefit from:

- fast, convenient online submission

- thorough peer review by experienced researchers in your field

- rapid publication on acceptance

- support for research data, including large and complex data types

- gold Open Access which fosters wider collaboration and increased citations

- maximum visibility for your research: over $100 \mathrm{M}$ website views per year

At BMC, research is always in progress.

Learn more biomedcentral.com/submissions 